\title{
Tissue distribution of residual antimony in rats treated with multiple doses of meglumine antimoniate
}

\author{
Deise Riba Coelho', Elaine Silva Miranda', \\ Tatiana Dillenburg Saint'Pierre ${ }^{2}$, Francisco José Roma Paumgartten ${ }^{1 /+}$
}

'Laboratório de Toxicologia Ambiental, Departamento de Ciências Biológicas, Escola Nacional de Saúde Pública-Fiocruz, Rio de Janeiro, RJ, Brasil ²Departamento de Química, Pontifícia Universidade Católica do Rio de Janeiro, Rio de Janeiro, RJ, Brasil

Meglumine antimoniate (MA) and sodium stibogluconate are pentavalent antimony $\left(S b^{V}\right)$ drugs used since the mid-1940s. Notwithstanding the fact that they are first-choice drugs for the treatment of leishmaniases, there are gaps in our knowledge of their toxicological profile, mode of action and kinetics. Little is known about the distribution of antimony in tissues after $S b^{V}$ administration. In this study, we evaluated the Sb content of tissues from male rats $24 \mathrm{~h}$ and three weeks after a 21-day course of treatment with MA (300 $\mathrm{mg} \mathrm{Sb}^{V} / \mathrm{kg}$ body wt/d, subcutaneous). Sb concentrations in the blood and organs were determined by inductively coupled plasma-mass spectrometry. In rats, as with in humans, the Sb blood levels after MA dosing can be described by a two-compartment model with a fast $t_{1 / 2}$ $=0.6 \mathrm{~h})$ and a slow $\left(t_{1 / 2}>>24 \mathrm{~h}\right)$ elimination phase. The spleen was the organ that accumulated the highest amount of $\mathrm{Sb}$, while bone and thyroid ranked second in descending order of tissues according to Sb levels (spleen >> bone, thyroid, kidneys $>$ liver, epididymis, lungs, adrenals $>$ prostate $>$ thymus, pancreas, heart, small intestines $>$ skeletal muscle, testes, stomach > brain). The pathophysiological consequences of Sb accumulation in the thyroid and Sb speciation in the liver, thyroid, spleen and bone warrant further studies.

Key words: pentavalent antimonials - thyroid - liver - leishmaniases - Glucantime - pharmacokinetics

Although it is a metalloid for which no natural biological function has been identified so far, antimony has a long history of medicinal uses. In the XVI century, Paracelsus, a famous alchemist and physician and one of the pioneers of iatrochemistry, was especially fond of antimony and prescribed medicines based on its salts for a number of morbid conditions (Haldar et al. 2011). During the following two centuries, antimony-based drugs became the centre of a dispute between Galenic school doctors and iatrochemists and the medical use of antimony was banned in France and other countries. In the earlyXX century, antimony-based drugs made a remarkable return to physicians' therapeutic armamentarium thanks to their efficacy in treating some parasitic diseases. In 1912, Gaspar Vianna reported that he had achieved a complete clinical cure for mucocutaneous leishmaniasis with a course of intravenous (i.v.) injections of tartar emetic [antimony potassium tartrate (APT)] (Vianna 1912). A few years later, in Italy, Di Cristina and Caronia (1915) successfully treated children afflicted with visceral leishmaniasis by injecting repeated doses of tartar emetic (Di Cristina \& Caronia 1915). Shortly thereafter, in Sudan, after confirming previous reports that i.v. injections of tartar emetic could cure cutaneous ("oriental sore") and visceral (kala-azar) forms of leishmaniases, John Christopherson noticed that this antimonial drug

doi: 10.1590/0074-0276140030

Financial support: FAPERJ, CNPq, INOVA-ENSP

$\mathrm{DRC}$ was the recipient of $\mathrm{PhD}$ fellowship from CNPq.

+ Corresponding author: paum@ensp.fiocruz.br

Received 24 January 2014

Accepted 4 June 2014 was also effective against both urinary and intestinal schistosomiases (Christopherson 1918, 1923). Since then and until the advent of praziquantel in the 1970s, trivalent antimonial drugs remained as one of the most effective therapeutic approaches for schistosomiasis.

As far as leishmaniasis therapy is concerned, tartar emetic and other $\mathrm{Sb}^{\mathrm{III}}$-based drugs were replaced by sodium stibogluconate (SSG) (Pentostam ${ }^{\circledR}$ ) and meglumine antimoniate (MA) (Glucantime ${ }^{\circledR}$ ), less toxic $\mathrm{Sb}^{\mathrm{V}}$ drugs that were introduced in the market in mid 1940s (Haldar et al. 2011).

The effective dosing schedules for antimony-based drugs in leishmaniasis and schistosomiasis were established decades before their complex kinetics were partially elucidated. The first kinetic investigations showed that patients excreted most of the antimony via urine within a few hours of injection of $\mathrm{Sb}^{\mathrm{III}}$ or $\mathrm{Sb}^{\mathrm{V}}$ drugs (Goodwin \& Page 1943, Otto et al. 1947). A clear picture of Sb kinetics, however, came to light only in 1988, when Chulay et al. (1988) reported that most of the Sb administered by a single intramuscular (i.m.) injection of $\mathrm{Sb}^{\mathrm{V}}$ is rapidly eliminated $\left(\mathrm{t}_{1 / 2}=2.02 \mathrm{~h}\right)$ so that only residual concentrations are found in the blood $24 \mathrm{~h}$ after drug administration. During a 30-day course of injections of $\mathrm{Sb}^{\mathrm{V}}$ spaced $24 \mathrm{~h}$ apart, however, these nadir $\mathrm{Sb}$ blood levels gradually rose. According to Chulay et al. (1988), their data on $\mathrm{Sb}$ blood levels could be described by a two-compartment kinetic model the slow elimination phase of which had a half-life of $76 \mathrm{~h}$. Based on the foregoing information, the authors speculated that the slow elimination phase was related to the in vivo conversion of $\mathrm{Sb}^{\mathrm{V}}$ into $\mathrm{Sb}^{\mathrm{III}}$, a bio-reduction that, according to them, could contribute to the toxicity often noted in long-term $\mathrm{Sb}^{\mathrm{v}}$ therapy. Further studies in humans and rhesus mon- 
keys using more sensitive analytical methods, suggested that $\mathrm{Sb}$ elimination could be even slower, with a terminal elimination half-life longer than 30 days (Miekeley et al. 2002, Friedrich et al. 2012). Moreover, data on speciation of $\mathrm{Sb}$ in monkeys' plasma one and nine days after a 21-day treatment course with MA indicated that the proportion of $\mathrm{Sb}^{\mathrm{III}}$ in nadir plasma levels of Sb markedly increased with time during the slow elimination phase, a finding that is consistent with the hypothesis that $\mathrm{Sb}^{\text {III }}$ becomes a major $\mathrm{Sb}$ species during the terminal elimination phase (Friedrich et al. 2012).

Despite the recent advances in the knowledge of antimonial drug kinetics, little is known about the distribution of $\mathrm{Sb}$ into tissues of individuals treated with $\mathrm{Sb}^{\mathrm{III}}$ or $\mathrm{Sb}^{\mathrm{V}}$ compounds. The same holds true for organ distribution of $\mathrm{Sb}$ following exposures through occupationally and environmentally relevant routes (i.e., oral, dermal or inhalation routes).

Molokhia and Smith (1969) measured (by neutron activation analysis) the $\mathrm{Sb}$ content of tissues of Schistosoma mansoni-infected mice at different time intervals $(0.5 \mathrm{~h}, 8 \mathrm{~h}, 24 \mathrm{~h}, 2,4,7$ and 15 days) after a single intraperitoneal (i.p.) injection of a Sb ${ }^{\mathrm{III}}$ drug (tartar emetic or sodium antimony 2,3 mesodimercapto-succinate, Astiban $^{\circledR}$ ). The authors found the highest levels of $\mathrm{Sb}$ in the liver and spleen, followed by alimentary tract organs (colon, duodenum and stomach), $30 \mathrm{~min}$ after treatment. Levels of $\mathrm{Sb}$ were similarly low in all tissues of mice euthanised on post-treatment day 4 and thereafter.

Recently, Borborema et al. (2013) determined the proportion of injected radioactive $\mathrm{Sb}\left({ }^{122} \mathrm{Sb}\right.$ and ${ }^{124} \mathrm{Sb}$ radioisotopes produced in neutron-irradiated Glucantime $^{\circledR}$ ) in tissues of Leishmania infantum chagasi-infected $(B A L B / c)$ mice treated with an i.p. injection of MA. Mice treated with $\mathrm{Sb}^{\mathrm{v}}$ were euthanised at post-treatment time intervals ranging from $3 \mathrm{~min}$ to three days. The highest $\%$ of Sb injected activities (IA) was found in the liver $30 \mathrm{~min}$ after the MA injection $(61 \%$ and $47.5 \%$ in non-infected and infected mice, respectively). According to the authors, measurable activities of Sb radioisotopes were also detected in spleen, intestines, stomach and kidneys, while no accumulation of radioactive $\mathrm{Sb}$ was noted in the brain, lungs, heart or uterus.

The foregoing studies shed some light on the tissue distribution of $\mathrm{Sb}$ after single doses of $\mathrm{Sb}^{\mathrm{III}}$ or $\mathrm{Sb}^{\mathrm{V}}$ drugs. Two additional studies determined Sb levels in organs of mice and rats exposed to APT for longer periods. Poon et al. (1998) exposed rats to APT orally (drinking water) for 90 days and described that levels of $\mathrm{Sb}$ in tissues [measured by inductively coupled plasma (ICP) emission spectrometry] were dose-related and followed a descending order of concentrations from liver and spleen to brain and adipose tissue [red blood cells (RBC) $>>$ spleen, liver $>$ kidneys $>$ brain, fat $>$ plasma]. Dieter et al. (1991) exposed $\mathrm{B} 6 \mathrm{C} 3 \mathrm{~F} 1$ mice and $\mathrm{F} 344$ rats to APT through the drinking water for 14 days and by i.p. injections every other day (a dosing schedule intended to minimise local mesenteric inflammation) for 90 days. The authors found dose-related concentrations of residual $\mathrm{Sb}$ in the blood, liver, kidney, spleen and heart of rats and in the liver and spleen of mice.
As far as the authors are aware, except for a previous study from our laboratory in rhesus monkeys infected with Leishmania braziliensis, residual levels of $\mathrm{Sb}$ in different tissues after a treatment course with $\mathrm{Sb}^{\mathrm{v}}$ drugs had not been investigated yet. This study was undertaken to provide data on the kinetics and tissue distribution of $\mathrm{Sb}$ in rats treated with a 21-day course of MA.

\section{MATERIALS AND METHODS}

Animals - Male Wistar rats from the Oswaldo Cruz Foundation (Fiocruz) breeding stock were used in this study. Upon arriving at the laboratory animal quarters, approximately 80 day-old rats were individually housed in standard plastic cages with stainless steel cover lids and pinewood shavings as bedding. Animals were kept under controlled environmental conditions (12 h light:12 h dark cycle, lights on from 08:00 am08:00 pm, temperature $22^{\circ} \mathrm{C} \pm 1{ }^{\circ} \mathrm{C}$, relative humidity approximately $70 \%$ ) throughout the study. All rats were given free access to a pelleted diet for rats and mice (CR1 Nuvital, Nuvilab Ltd, Brazil) and tap water. Experiments were conducted in accordance with Brazilian animal protection and welfare laws and the study protocol was cleared by the Ethical Committee on the Use of Laboratory Animals of Fiocruz.

Treatment - MA (Glucantime ${ }^{\circledR}$, Sanofi-Aventis Farmacêutica Ltd, Brazil) was administered by i.v. injections (penis vein) or by subcutaneous (s.c.) injections on the back skin of the rat. MA is a poorly characterised drug that is produced by the reaction of $\mathrm{Sb}^{\mathrm{v}}$ with $\mathrm{N}$-methyl-D-glucamine. Evidence has been provided that up to $4 \mathrm{~N}$-methyl-D-glucamine hydroxyls are coordinated with each antimony atom (Roberts et al. 1998). According to the manufacturer, each ampoule $(5 \mathrm{~mL})$ of Glucantime ${ }^{\circledR}$ contains $425 \mathrm{mg} N$-methyl MA/mL or $85 \mathrm{mg} \mathrm{Sb}^{\mathrm{V}}$ / $\mathrm{mL}$. Traces of $\mathrm{Sb}^{\mathrm{III}}$ are commonly found in pharmaceutical formulations of MA. The content of $\mathrm{Sb}^{\mathrm{III}}$ in MA ampoules varies between lots of the drug and very different concentrations (up to $10 \mathrm{mg} / \mathrm{mL}$ ) have been reported in the literature. Total $\mathrm{Sb}, \mathrm{Sb}^{\mathrm{V}}$ and $\mathrm{Sb}^{\mathrm{III}}$ concentrations were determined in the Glucantime ${ }^{\circledR}$ lot used in this investigation and also in ampoules of additional lots. Levels of total $\mathrm{Sb}$ in ampoules from the lot used in this study was $90.1 \mathrm{mg} / \mathrm{mL}$ while the concentration of $\mathrm{Sb}^{\mathrm{III}}$ [measured by hydride generation-ICP-mass spectrometry (MS) as described by Miekeley et al. (2002)] was $3.2 \mathrm{mg} / \mathrm{mL}$ or $3.5 \%$ total $\mathrm{Sb}$, while the concentration of $\mathrm{Sb}^{\mathrm{v}}$ [(Sb-total) - $\left.\left(\mathrm{Sb}^{\mathrm{III}}\right)\right]$ was $86.9 \mathrm{mg} / \mathrm{mL}$. In ampoules from two additional lots of Glucantime ${ }^{\circledR}$ (not used in this study) $\mathrm{Sb}$ concentrations were $85 \mathrm{mg} / \mathrm{mL}$ and $87.6 \mathrm{mg} / \mathrm{mL}, 3.8 \%$ and $3.9 \%$ of which as $\mathrm{Sb}^{\mathrm{III}}$ (Friedrich et al. 2012).

The injected doses were $75 \mathrm{mg} \mathrm{Sb} / \mathrm{mg} / \mathrm{kg}$ body wt (single dose, i.v.) or $300 \mathrm{mg} \mathrm{Sb} / \mathrm{kg}$ body wt/d (s.c.) and injection volumes were $0.88 \mathrm{~mL} / \mathrm{kg}$ body or $3.5 \mathrm{~mL} / \mathrm{kg}$ body wt/d, respectively. A vehicle-only treated control group $(\mathrm{n}=6)$ received s.c. injections $(1.76 \mathrm{~mL} / \mathrm{kg}$ body $\mathrm{wt} / \mathrm{d}$ ) of the vehicle (potassium metabisulfite, $1.6 \mathrm{mg} / \mathrm{mL}$ and sodium sulfite, $0.18 \mathrm{mg} / \mathrm{mL}$ ). In a preliminary test, six animals were injected intravenously with a single dose of MA (75 mg Sb$/ \mathrm{mg} / \mathrm{kg}$ body wt) to evaluate the fast elimination phase of Sb kinetics in the male rat. In a 
subsequent experiment, 12 rats were treated by the s.c. route with a dose of MA as high as $300 \mathrm{mg} \mathrm{Sb} / \mathrm{kg}$ body $\mathrm{wt} / \mathrm{d}$ for 21 days. Half of the MA-treated rats were euthanised 24-h after the last dose of MA while the remaining animals were euthanised 21 days later. A third experiment (6 MA-treated and 3 vehicle-control rats) was performed to evaluate the extent to which residual $\mathrm{Sb}$ blood levels declined after the end of a 21-d course of treatment with MA (300 mg Sbv/kg body wt/d, s.c.) when a longer post-treatment time interval (105 days) was examined. Rats were euthanised by carbon dioxide inhalation.

Antimony determination in biological matrices - Levels of $\mathrm{Sb}$ in biological matrices (whole blood, plasma and tissues) were determined by ICP-MS as described in detail elsewhere (Miekeley et al. 2002, Friedrich et al. 2012).

An ELAN DRC II (PerkinElmer Sciex, USA) instrument equipped with a Meinhard nebuliser and a cyclonic spray chamber (Glass Expansion, Australia) was used. Antimony measured isotopes ${ }^{121} \mathrm{Sb},{ }^{123} \mathrm{Sb}$ and ${ }^{103} \mathrm{Rh}$ were employed as internal standards. To determine total $\mathrm{Sb}$ by solution nebulisation ICP-MS, whole blood and plasma samples were analysed after digestions with two-fold subboiled distilled $\mathrm{HNO}_{3}$ and adequate dilution (1:10 or 1:100) with deionised water $(18 \mathrm{M} \Omega \mathrm{cm}$ minimum resistivity, MilliQ, Millipore, USA). Tissue samples were lyophilised and wet-ashed with $\mathrm{HNO}_{3}-\mathrm{H}_{2} \mathrm{O}_{2}$ in closed polyethylene tubes essentially as previously reported (Miekeley et al. 2002). The diluted digest was then analysed by ICP-MS in the quantitative external calibration method.

The accuracy of the method was checked by the analysis of a reference material (bovine whole blood provided by the Adolpho Lutz Institute, Brazil) and a tissue (liver) from a control individual. The Sb concentration in these samples was below the limit of detection (LOD). The samples were spiked with $10 \mu \mathrm{g} / \mathrm{L}$ and 60 $\mu \mathrm{g} / \mathrm{L}$ of $\mathrm{Sb}$ and recoveries were between $96-99.7 \%$ (10 $\mu \mathrm{g} / \mathrm{L})$ and between $101.9-102.8 \%(60 \mu \mathrm{g} / \mathrm{L})$, respectively. The relative standard deviation was below 5\%. The repeatability (calculated as $\mathrm{r}=\mathrm{t}_{(\mathrm{n}-1,1-\alpha)} \cdot \sqrt{2} \mathrm{~g} \mathrm{~s}$ ) was $1.8 \mu \mathrm{g} / \mathrm{L}$ and $10.9 \mu \mathrm{g} / \mathrm{L}$ for the spikes of $10 \mu \mathrm{g} / \mathrm{L}$ and $60 \mu \mathrm{g} / \mathrm{L}$, respectively. The LOD of the method were $0.5 \mathrm{ng} \mathrm{Sb} / \mathrm{g}$ for plasma and whole blood and $1 \mathrm{ng} \mathrm{Sb} / \mathrm{g}$ for tissues, while limits of quantification (LOQ) were $1.7 \mathrm{ng} \mathrm{Sb} / \mathrm{g}$ for plasma and whole blood and $3.3 \mathrm{ng} \mathrm{Sb} / \mathrm{g}$ for tissues. The analytical solutions were prepared from $\mathrm{Sb}^{\mathrm{V}}\left(\mathrm{KSb}(\mathrm{OH})_{6}\right.$, p.a. Merck) and $\mathrm{Sb}^{\mathrm{III}}\left(\mathrm{C}_{4} \mathrm{H}_{4} \mathrm{KO}_{7} \mathrm{Sb}+0.5 \mathrm{H}_{2} \mathrm{O}\right.$, p.a. Merck) stock solutions $(1,000 \mathrm{mg} / \mathrm{L})$ in water.

Blood sampling - Venous blood samples $(0.5 \mathrm{~mL})$ were taken from the tail vein prior to MA treatment (d 0) and immediately before injections on treatment days 1 , $5,9,13,18$ and on post-treatment days $1,4,8,12,16$ and 21. Na-heparin was used as anticoagulant and plasma was separated by centrifugation $(2,400 \mathrm{~g}$ for $15 \mathrm{~min})$. Whole blood and plasma samples were distributed into polyethylene tubes and kept at $-20^{\circ} \mathrm{C}$ until further use.

Statistical analysis - Data were evaluated by ANOVA and Dunnett's test, by the Student $t$ test or, when results did not fit a normal distribution, by the Kruskal-Wallis test followed by the Mann-Whitney $U$ test. In any case, a difference was considered significant for $\mathrm{p}<0.05$. Descriptive statistics, statistical inference tests and linear regression were performed using SPSS (v.11) or a Graph Pad Prism 45 software.

\section{RESULTS}

Blood levels of Sb after single and multiple doses of $M A$ - Fig. 1A depicts the time course of changes in whole blood levels of $\mathrm{Sb}$ after a single i.v. (bolus) injection of MA ( $75 \mathrm{mg} \mathrm{Sb} / \mathrm{kg}$ body wt) given to male rats. The sharp fall in Sb blood concentrations $\left(\mathrm{t}_{1 / 2}=0.6 \mathrm{~h}\right)$ indicates that almost all $\mathrm{Sb}$ given as MA was cleared from the body within 6-12 h of drug injection. Nonetheless, a closer look at $\mathrm{Sb}$ terminal elimination phase (Fig. 1A, insert) reveals that, after attaining concentrations as low as $2 \mu \mathrm{g} / \mathrm{g}$ or less within $6 \mathrm{~h}$ of administration, further elimination proceeds very slowly so that $24 \mathrm{~h}$ after an i.v. injection of $\mathrm{MA}$, nadir levels of $\mathrm{Sb}$ are found in the blood. Similar fast elimination phases of $\mathrm{Sb}$ with very low residual levels 24 $\mathrm{h}$ after MA administration were also observed when a $\mathrm{Sb}^{\mathrm{V}}$ drug is given to rats by the s.c. route (Miranda et al. 2006). In this study, we did not examine the fast elimination following s.c. administration, but Fig. 2 shows the increase in nadir blood levels of $\mathrm{Sb}$ (measured $24 \mathrm{~h}$ after a previous injection) during the treatment course period and the slow decline of $\mathrm{Sb}$ concentrations thereafter. As shown in Fig. 2, upon repeated administration (by the s.c. route) of $24 \mathrm{~h}$ spaced doses of MA ( $300 \mathrm{mg} \mathrm{Sb} / \mathrm{kg}$ body $\mathrm{wt} / \mathrm{d}$, s.c.), nadir levels of $\mathrm{Sb}$ steadily rose so that at the end of a 21-day course of treatment, $\mathrm{Sb}$ attained levels as high as $35-40 \mu \mathrm{g} / \mathrm{g}$ in whole blood. Blood levels of $\mathrm{Sb}$ in rats euthanised one day after the last dose of MA (on day 22) did not differ from the levels of this metalloid in the blood of rats euthanised 21 days later (on day 42). In a subsequent experiment, six rats were treated with MA (300 mg Sb$/ \mathrm{kg}$ body wt/d, s.c.) for 21 days and their $\mathrm{Sb}$ blood levels were measured on the day following the last dose of MA (day 22) and 105 days later (day 126). The results showed that after almost three months post-treatment, Sb blood levels fell modestly from $51.0 \pm 7.3 \mu \mathrm{g} / \mathrm{g}$ (day 22) to $35.6 \pm 4.6 \mu \mathrm{g} / \mathrm{g}$ (day 126). Sb levels in whole blood of control (untreated and vehicle only-treated) rats remained undetected or close to the LOQ.
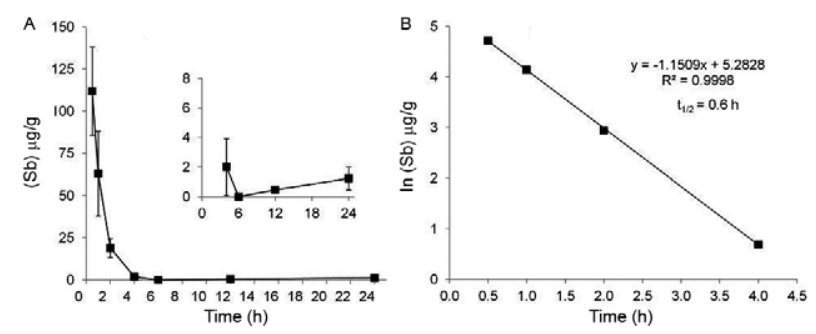

Fig 1A: time course of antimony $(\mathrm{Sb})$ concentrations $(\mu \mathrm{g} / \mathrm{g})$ in the blood (whole blood) of male rats $(n=6)$ treated intravenously with a single dose (75 $\mathrm{mg} \mathrm{Sb} / \mathrm{kg}$ body $\mathrm{wt}$ ) of meglumine antimoniate (MA) [insert: a magnified view of nadir Sb levels at post-injection intervals longer than $6 \mathrm{~h}$ (terminal elimination phase)]; B: linear plot of decline in Sb blood levels during the fast elimination phase. Data are shown as natural logarithm of $\mathrm{Sb}$ concentration $(\mu \mathrm{g} / \mathrm{g})$ in the blood vs. time after MA administration. 
Residual levels of Sb in tissues after a 21-day course of treatment with MA - Tissue concentrations of $\mathrm{Sb}$ were determined in rats killed $24 \mathrm{~h}$ after the last dose of MA and in a second group of animals killed 21 days after treatment discontinuation (Table I). Fig. 3 shows the distribution of $\mathrm{Sb}$ in the spleen, kidneys, femur, thyroid, liver, epididymis, lungs and adrenals, all of which presented $\mathrm{Sb}$ levels higher than $5 \mu \mathrm{g} / \mathrm{g}$ at the end of treatment. The spleen ranked first among the tissues with the highest levels of $\mathrm{Sb}$ at the end of treatment. Although declining markedly over a three-week post-treatment period, levels of $\mathrm{Sb}$ in the spleen were still the highest among all tissues on day 42 (Table I). The kidneys, bones (femur) and thyroid gland ranked second in a descending order of $\mathrm{Sb}$ content in tissues at the end of MA administration period (Table I). In contrast to the bones and thyroid, the $\mathrm{Sb}$ levels which exhibited a small reduction, kidney levels showed a drastic decline during the three post-treatment weeks. The liver, epididymis, lungs and adrenals showed intermediate levels of $\mathrm{Sb}$ at the end of treatment (Table I). On day 42, levels of Sb in the liver and epididymis were markedly lower than the levels on the day after the last dose of MA, while levels in lungs and adrenals were modestly reduced. Fig. 4 presents tissues that showed the lowest concentrations of $\mathrm{Sb}(<5 \mu \mathrm{g} / \mathrm{g})$ after a course of treatment with MA. The tissues with low $<<$ $5 \mu \mathrm{g} / \mathrm{g}) \mathrm{Sb}$ concentrations on day 22 that exhibited a further reduction of metalloid content within the next three weeks were as follows: prostate, thymus, small intestine, skeletal muscle, testes and stomach. The tissues which did not exhibit a discernible change in Sb levels between days 22-42 were pancreas, heart and brain (Table I).

Whole blood and plasma Sb levels 105 days after the end of treatment with MA are shown in Table II. The huge difference between whole blood and plasma concentrations of $\mathrm{Sb}$ is consistent with the notion that at this terminal elimination phase RBCs account for almost all $\mathrm{Sb}$ contained in the blood. It is of note that levels of antimony in the blood and plasma of untreated and vehicleonly treated rats were extremely low or below the quantification and/or detection limits.

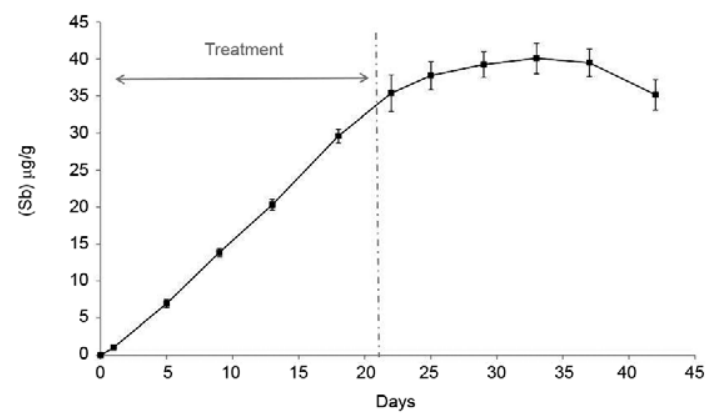

Fig 2: time course of nadir concentrations of antimony $(\mu \mathrm{g} / \mathrm{g})$ in the blood from male rats $(n=6)$ treated with meglumine antimoniate (MA) (300 mg Sb $/ \mathrm{kg}$ body wt, subcutaneous) during 21 consecutive days. Blood samples were taken from the tail vein $24 \mathrm{~h}$ after a prior MA administration. Levels of $\mathrm{Sb}$ in the blood of untreated controls ( $\mathrm{n}$ $=3$ ) and of rats treated with the vehicle only $(n=6)$ (not shown) were below the limit of quantification of the method.

\section{DISCUSSION}

Data provided by this study indicated that, in male rats treated with MA, a decline of Sb levels in the blood can be described by a two-compartment kinetic model with fast $\left(t_{1 / 2}=0.6 \mathrm{~h}\right)$ and slow elimination phases. Similar biexponential declines in $\mathrm{Sb}$ blood concentration over time had been described for pregnant and non-pregnant female rats treated with MA (Miranda et al. 2006) and also for dogs (Tassi et al. 1994), mice (Nieto et al. 2003), hamsters (Radwan et al. 2007), non-human primates (Friedrich et al. 2012) and humans (Chulay et al. 1988, Miekeley et al. 2002) treated with $\mathrm{Sb}^{\mathrm{V}}$ drugs by parenteral routes.

There is a paucity of data on the distribution of $\mathrm{Sb}$ into different tissues and on their elimination from the body after exposure to organic antimony compounds or even to inorganic antimony. As mentioned in the introduction of this article, Borborema et al. (2013) has recently described the distribution of labelled $\mathrm{Sb}\left({ }^{122} \mathrm{Sb}\right.$, ${ }^{124} \mathrm{Sb}$ ) into some BALB/c mouse tissues at different time intervals after a single i.p. injection of MA. A study by Molokhia and Smith (1969) also reported the distribution of $\mathrm{Sb}$ into a variety of mouse tissues following a single i.p. administration of $\mathrm{Sb}^{\mathrm{III}}$ schistosomicidal drugs. The foregoing studies described the distribution of $\mathrm{Sb}$ after single injections of antimonial drugs. There are only a few studies on the tissue distribution of residual $\mathrm{Sb}$ after prolonged exposures through drinking water or repeated

TABLE I

Concentrations of antimony $(\mu \mathrm{g} / \mathrm{g})$ in rat tissues 24-h and 21-days after a 21-days treatment with meglumine antimoniate $(\mathrm{MA})^{a}$

\begin{tabular}{lcc}
\hline & \multicolumn{2}{c}{ Time after the last injection of MA } \\
\cline { 2 - 3 } Tissue & 1 day & 21 days \\
\hline Spleen & $148.0 \pm 14.0$ & $81.9 \pm 4.6^{b}$ \\
Kidneys & $31.1 \pm 1.9$ & $5.4 \pm 0.4^{b}$ \\
Femur & $28.2 \pm 0.7$ & $18.3 \pm 0.8^{b}$ \\
Thyroid gland & $25.2 \pm 4.5$ & $18.0 \pm 1.2$ \\
Liver & $13.8 \pm 1.3$ & $3.2 \pm 0.2^{b}$ \\
Epididymis & $10.9 \pm 0.7$ & $1.2 \pm 0.1^{b}$ \\
Lungs & $10.2 \pm 0.8$ & $7.7 \pm 0.7^{b}$ \\
Adrenals & $7.4 \pm 0.5$ & $5.9 \pm 0.5$ \\
Prostate & $3.2 \pm 0.5$ & $1.0 \pm 0.2^{b}$ \\
Thymus & $3.1 \pm 0.2$ & $1.6 \pm 0.2^{b}$ \\
Small intestines & $2.7 \pm 0.3$ & $1.8 \pm 0.3^{b}$ \\
Skeletal muscle & $2.2 \pm 0.4$ & $0.6 \pm 0.1^{b}$ \\
Testes & $2.0 \pm 0.1$ & $1.0 \pm 0.2^{b}$ \\
Stomach & $1.7 \pm 0.2$ & $1.0 \pm 0.1^{b}$ \\
Pancreas & $3.0 \pm 0.4$ & $2.5 \pm 0.4$ \\
Heart & $2.8 \pm 0.3$ & $2.7 \pm 0.3$ \\
Brain & $0.6 \pm 0.0$ & $0.5 \pm 0.0$ \\
\end{tabular}

$a: 300 \mathrm{mg} \mathrm{mg} \mathrm{SbV/kg} \mathrm{body} \mathrm{wt/d} \mathrm{subcutaneous;} b$ : differ from $\mathrm{Sb}$ concentrations measured 24-h after treatment (Student $t$ test, $\mathrm{p}<$ 0.05 ). Values are means \pm standard deviation, $\mathrm{n}=6$ rats/group. 
injections of $\mathrm{Sb}^{\mathrm{III}}$ organic compounds (e.g., tartar emetic) (Dieter et al. 1991, Poon et al. 1998). As far as the authors are aware, except for a report on Sb levels in organs from rhesus monkeys treated with MA (Friedrich et al. 2012), no study has provided data on Sb distribution into tissues after a course of treatment with $\mathrm{Sb}^{\mathrm{V}}$ drugs.

The marked disproportion between Sb levels in whole blood and in plasma 105 days after the end of treatment of with MA (Table II) is consistent with the hypothesis that, during the terminal slow elimination phase, $\mathrm{Sb}$ is found inside RBCs with very little in plasma. Friedrich et al. (2012) reported that, in monkeys that received i.m. injections of MA, the ratio of the $\mathrm{Sb}$ concentration in the plasma to the $\mathrm{Sb}$ concentration in $\mathrm{RBC}\left[(\mathrm{Sb})_{\text {plasma }} /(\mathrm{Sb})_{\mathrm{RBC}}\right]$ was $>1$, but progressively diminished with time in the fast elimination phase (e.g., 6 and $12 \mathrm{~h}$ post-dosing). An inverse ratio $(<1)$, however, was noted in the slow elimination phase (e.g., 24-h and longer post-treatment time intervals). Along the same line, a study by Quiroz et al. (2009) found that the levels of Sb-total in the blood of workers occupationally exposed to $\mathrm{Sb}$ in the air (vehicle

$(\mathrm{Sb})>5 \mu \mathrm{g} / \mathrm{g}$

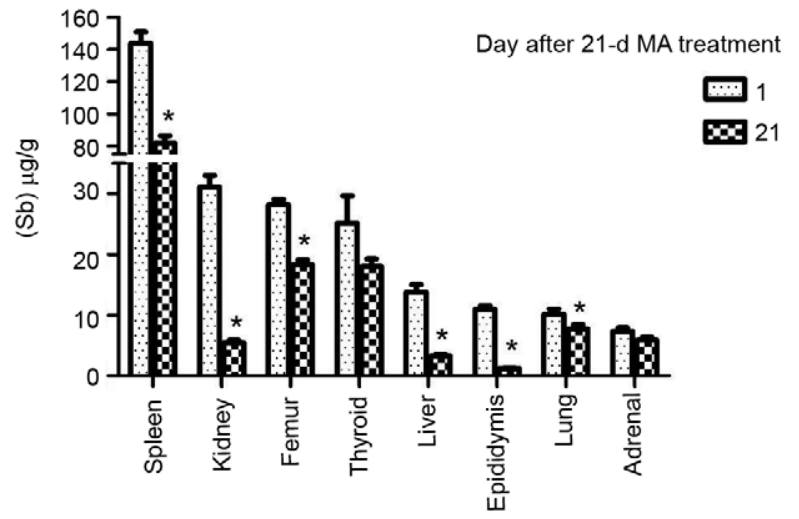

Fig. 3: tissues the residual antimony levels of which were higher than $5 \mu \mathrm{g} / \mathrm{g}$. Sb content $(\mu \mathrm{g} / \mathrm{g}$, dry wt) was determined by inductively coupled plasma-mass spectrometry in rats killed $24 \mathrm{~h}(\mathrm{n}=6)$ and 21 days $(\mathrm{n}=6)$ after a 21-d treatment with meglumine antimoniate (MA) (300 $\mathrm{mg} \mathrm{Sb} / \mathrm{kg}$ body wt/d, subcutaneous). Asterisks mean a decrease (Student $t$ test, $\mathrm{p}<0.05$ ) of Sb concentration within three weeks of the end of MA administration. emissions) were higher in the RBCs than in the plasma. In a recent study, Quiroz et al. (2013) spiked human blood samples (in vitro) with $\mathrm{Sb}^{\mathrm{III}}$ (APT) and $\mathrm{Sb}^{\mathrm{V}}\left[\mathrm{KSb}(\mathrm{OH})_{6}\right]$ and demonstrated that both species penetrate the RBC membrane and leave the cell cytoplasm with time.

Many authors believe that some of the $\mathrm{Sb}^{\mathrm{v}}$ that penetrates the erythrocyte is intracellularly reduced to $\mathrm{Sb}^{\mathrm{III}}$, a form that is retained within the cell by forming complexes with organic ligands, such as glutathione (GSH) (Haldar et al. 2011). A hypothesis has also been suggested that, while the initial rapid elimination (via urine) is governed by a major pool of $\mathrm{Sb}$ (or Sbv in the case of MA and SSG) that remained in the extracellular medium (including plasma), the slow terminal phase is governed by an intracellular $\mathrm{Sb}$ pool, the mobilisation of which is slow (Friedrich et al. 2012).

The spleen was the organ that ranked first in a descending order of tissues according to $\mathrm{Sb}$ residual content after treatment with MA (Fig. 3). The marked accumulation of $\mathrm{Sb}$ in the spleen is possibly explained by some of the organ's functions, such as to hold a reserve
$(\mathrm{Sb})<5 \mu \mathrm{g} / \mathrm{g}$

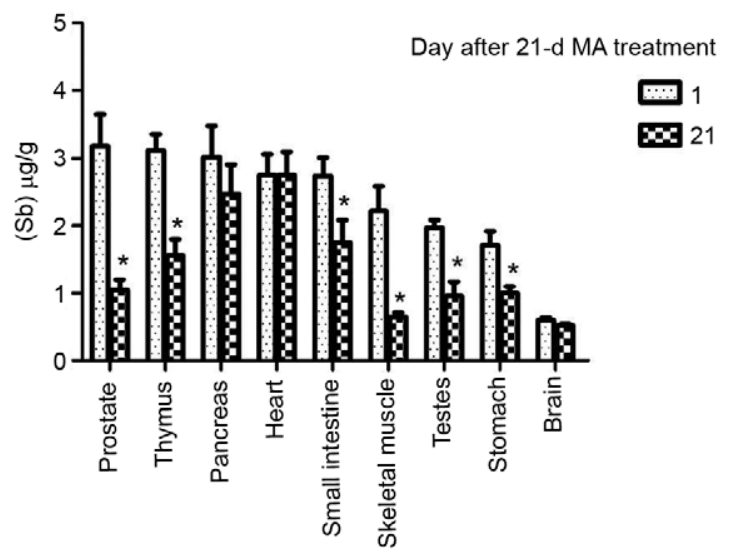

Fig. 4: tissues the residual antimony levels of which were lower than $5 \mu \mathrm{g} / \mathrm{g}$. Sb content $(\mu \mathrm{g} / \mathrm{g}$, dry wt) was determined by inductively coupled plasma-mass spectrometry in rats killed $24 \mathrm{~h}(\mathrm{n}=6)$ and 21 days $(\mathrm{n}=6)$ after a 21-d treatment with meglumine antimoniate (MA) (300 $\mathrm{mg} \mathrm{Sb} / \mathrm{kg}$ body wt/d, subcutaneous). Asterisks mean a decrease (Student $t$ test, $\mathrm{p}<0.05$ ) of Sb concentration within three weeks of the end of MA administration

\section{TABLE II}

Levels of antimony (Sb) in the whole blood and plasma of male rats 105 days after the end of a 21-days course of treatment with the vehicle-only (controls) or meglumine antimoniate (MA) ${ }^{a}$

\begin{tabular}{|c|c|c|}
\hline Treatment & $\begin{array}{c}\text { Vehicle-only } \\
(1.76 \mathrm{~mL} / \mathrm{kg} \text { body } \mathrm{wt} / \mathrm{d}, \text { s.c. x } 21 \mathrm{~d}) \\
(\mathrm{ng} / \mathrm{g})\end{array}$ & $\begin{array}{c}\text { MA } \\
\left(300 \mathrm{mg} \mathrm{Sb}^{\mathrm{V}} / \mathrm{kg} \text { body wt/d, s.c. } \times \text { } 21 \mathrm{~d}\right) \\
(\mathrm{ng} / \mathrm{g})\end{array}$ \\
\hline Whole blood & $3 \pm 0$ & $35,614 \pm 4,625$ \\
\hline Plasma & $<\mathrm{LOQ}^{b}$ & $21 \pm 12$ \\
\hline
\end{tabular}

$a: 300 \mathrm{mg} \mathrm{Sb} / \mathrm{kg}$ body $\mathrm{wt} / \mathrm{d}$, subcutaneous (s.c.); $b$ : levels below the limit of quantification (LOQ) of the method (1.7 ng Sb/g). Data are shown as the means \pm standard deviation of Sb concentrations (wet wt) determined by inductively coupled plasma-mass spectrometry. Vehicle-only group, $n=6$; MA-treated group, $n=6$. 
of blood and to remove senescent erythrocytes (Mebius \& Kraal 2005). Moreover, erythrophagocytosis by the spleen and liver macrophages and the scavenging of haemoglobin (and haptoglobin-bound haemoglobin) from the circulation by splenic macrophages play a key role in iron recycling (Mebius \& Kraal 2005). Antimony speciation and the fate (metabolomics) within the splenic and liver tissues, however, are still obscure questions. Spleen has been reported to be one of the tissues with the highest residual concentrations of $\mathrm{Sb}$ in mice treated with a single injection of $\mathrm{Sb}^{\mathrm{III}}$ (Molokhia \& Smith 1969) or $\mathrm{Sb}^{\mathrm{V}}$ (Borborema et al. 2013) drugs and in rats and mice exposed by the oral or i.p. route to $\mathrm{Sb}^{\mathrm{III}}$ (tartar emetic) for 90 days (Dieter et al. 1991, Poon et al. 1998).

Among all rat tissues examined in this study, the brain (whole brain) had the lowest residual levels of $\mathrm{Sb}$. Friedrich et al. (2012) also found that, in monkeys treated with MA, the central nervous system (CNS) structures (frontal and occipital lobes, parietal and temporal lobes, mesencephalon, medulla oblongata and cerebellum) were the tissues that exhibited the lowest levels of Sb. The brain also had the lowest residual levels of antimony in rodents treated with a single (Molokhia \& Smith 1969) or multiple doses of tartar emetic (Dieter et al. 1991, Poon et al. 1998). These findings in rodents and non-human primates are consistent with the hypothesis that the blood-brain barrier prevents the penetration of $\mathrm{Sb}^{\mathrm{III}}$ and $\mathrm{Sb}^{\mathrm{V}}$ into the brain.

A remarkable finding of this study was that the thyroid gland of rats treated with MA accumulated a high content of $\mathrm{Sb}$ and that no decline of $\mathrm{Sb}$ concentrations occurred in the organ over three post-treatment weeks. In the rat, the levels of $\mathrm{Sb}$ in the thyroid gland were higher than the levels in the liver and comparable to levels found in the bones (Fig. 3). Along the same line, Friedrich et al. (2012) had reported that, in monkeys treated with a low and a standard MA dosage regimen, the thyroid was the analysed tissue with the highest content of Sb. Although the marked accumulation of $\mathrm{Sb}$ by the thyroid during treatment with $\mathrm{Sb}^{\mathrm{III}}$ or $\mathrm{Sb}^{\mathrm{V}}$ drugs remained almost unnoticed in the medical literature, it had already been noted in a few older studies with $\mathrm{Sb}^{\mathrm{III}}$ compounds. Brady et al. (1945), for instance, treated dogs infected with Dirofilaria immitis with APT (labelled with ${ }^{124} \mathrm{Sb}$ ) and found that while the liver ranked first in Sb content, combined thyroid and parathyroid were the tissues with the second largest accumulation of radioactive Sb. Kramer (1950) treated male rabbits with tartar emetic (once a day for 21 days i.v.) and noted that $\mathrm{Sb}$ concentrations in the thyroid were appreciably higher than those in any other tissue (kidneys, muscle and spleen) with the exception of the liver. According to Kramer (1950), Sb accumulation in the rabbit thyroid was not accompanied by changes of gland function or histology. In human volunteers who received sodium antimony mercapto-succinate (labelled with ${ }^{124} \mathrm{Sb}$ ) by the i.v. route, Abdallah and Saif (1962) noted that the highest radioactivity was recorded in the liver, followed by that in the thyroid and in the heart. Poon et al. (1998) did not determine Sb levels in the gland of rats exposed to APT, but they reported some treatmentrelated histological abnormalities, such as reduced fol- licle size, increased epithelial height and nuclear vesiculation, all of which are morphological changes that have been interpreted as reflecting a mild adaptive change of thyroid function of minor or no toxicological importance (Lynch et al. 1999). At any rate, localisation of $\mathrm{Sb}$ forms within the thyroid tissue and possible influences of $\mathrm{Sb}$ accumulation on gland function deserve further studies.

The Sb levels in epididymis and prostate fell markedly over the three post-treatment weeks so that residual levels of $\mathrm{Sb}$ in all male reproductive organs (epididymis, prostate and testes) were consistently low three weeks after the end of treatment with MA. The low residual levels of $\mathrm{Sb}$ in male reproductive organs is consistent with our previous findings, suggesting that treatment of rats during gestation and lactation periods with MA (doses up to 300 $\mathrm{mg} \mathrm{Sb} / \mathrm{kg}$ body wt/d, s.c.) did not affect offspring sperm parameters and male fertility in adulthood (Coelho 2010).

Stomach, small intestines and pancreas were among the rat organs that presented the lowest residual content of $\mathrm{Sb}(<5 \mu \mathrm{g} / \mathrm{g})$ after a 21-day course of treatment with MA. Friedrich et al. (2012) did not measure Sb content in the small intestines, but found that stomach, colon and pancreas were among the analysed monkey tissues that had the lowest concentrations of Sb 55 and 95 days after a 21-day treatment with MA. Molokhia and Smith (1969), however, found that colon, duodenum and stomach were, following liver and spleen, the murine tissues with the most elevated $\mathrm{Sb}$ levels $0.5 \mathrm{~h}$ after a single i.p. injection of tartar emetic. Borborema et al. (2013) reported that, in mice treated with a single i.p. injection of irradiated MA $\left({ }^{122} \mathrm{Sb},{ }^{124} \mathrm{Sb}\right), \%$ of IA in the small intestines fell from nearly $13 \%$ ( $3 \mathrm{~min}$, non-infected mice) to less than $2 \%$ within $24 \mathrm{~h}$ of dosing, while in the large intestines \% IA was approximately $1 \%$ at $0.5 \mathrm{~h}$, rose to approximately $16 \%$ at $2 \mathrm{~h}$ and fell to approximately $2 \%$ at $24 \mathrm{~h}$ after drug administration. The authors interpreted the foregoing findings as reflecting a primary elimination of $\mathrm{Sb}$ through hepatobiliary excretion after liver processing.

It should be noted, however, that both Borborema et al. (2013) and Molokhia and Smith (1969) injected a Sb and a $\mathrm{Sb}^{\text {III }}$ drug, respectively, into the peritoneal cavity, where liver, pancreas, stomach and small and large intestines are located. Under those conditions, the $\mathrm{Sb}$ levels determined by the authors may eventually reflect not only the $\mathrm{Sb}$ that reached the tissue indirectly via systemic circulation, but also the $\mathrm{Sb}$ that was absorbed directly by the tissue at the site of injection. Moreover, Borborema et al. (2013) interpretation that during the fast elimination phase (within $12 \mathrm{~h}$ of the injection) $\mathrm{Sb}$ from MA is cleared primarily through hepatobiliary excretion is at odds with data provided by most studies. In fact, results from several studies are consistent with the notion that during rapid elimination phase, $\mathrm{Sb}^{\mathrm{III}}$ is excreted via bile and to a lesser extent via urine, whereas the reverse holds true for $\mathrm{Sb}^{\mathrm{v}}$. Bailly et al. (1991), for instance, demonstrated that after a single i.v. administration of $\mathrm{Sb}^{\text {III }}$ (APT) to rats, about the same percentage $(50 \%)$ of the administered $\mathrm{Sb}$ was excreted in the urine and faeces, whereas after i.p. injection, about four times more $\mathrm{Sb}$ was excreted in the faeces than in the urine. The hepatobiliary transport of $\mathrm{Sb}^{\mathrm{III}}$ is GSH-dependent. 
Along this line, it was described that the i.v. administration of APT increased up to 50-fold the biliary excretion of non-protein thiols (mainly GSH) by the rat (Gyurasics et al. 1992, Gregus et al. 1998). Transport of $\mathrm{Sb}^{\mathrm{v}}$ from MA into the bile apparently requires its reduction to $\mathrm{Sb}^{\mathrm{III}}$ and the intracellular reduction of $\mathrm{Sb}^{\mathrm{V}}$ is promoted by GSH and other thiols found in the cytosol (Ferreira et al. 2003). Based on the foregoing, it seems plausible to think that hepatobiliary excretion plays a major role in the elimination of residual $\mathrm{Sb}$ (mainly as $\mathrm{Sb}^{\mathrm{III}}$ ) during the slow terminal elimination phase after a course of treatment with $\mathrm{Sb}^{\mathrm{v}}$ drugs. Nonetheless, Borborema et al. (2013) hypothesis that $\mathrm{Sb}^{\mathrm{v}}$ is excreted primarily in the bile during the rapid elimination phase needs to be substantiated by experimental data.

In this study, the bone was the tissue with the second highest $\mathrm{Sb}$ concentration after spleen and next to thyroid, while the skeletal muscle ranked among rat tissues with the lowest levels of Sb. In monkeys treated with MA, both bone (femur) and skeletal muscle were among the tissues classified by Friedrich et al. (2012) as having accumulated "intermediate" levels of Sb. As far as the authors are aware, these are the only two studies that measured $\mathrm{Sb}$ residual levels in bone and muscle after a treatment course with MA.

In conclusion, the decline of Sb blood levels with time after a parenteral injection of MA can be described by a two-compartment model, with a fast elimination phase the half-life of which was $0.6 \mathrm{~h}$ and a very slow terminal elimination phase, the half-life of which is longer than 24 h. A course of treatment of rats with $24 \mathrm{~h}$ spaced doses of MA, therefore, results in a gradual increase of nadir $\mathrm{Sb}$ levels in blood, a kinetic behaviour similar to that described for humans, non-human primates, dogs and mice. This kinetic similarity with humans makes the rat a suitable model for studies of $\mathrm{Sb}^{\mathrm{V}}$ distribution in tissues and toxicity. Furthermore, data from this study also showed that during the terminal elimination phase, the highest residual concentrations were found in the spleen, bones, thyroid gland and the liver. The levels in the kidneys were high at the end of treatment but decline sharply within three post-treatment weeks, a fall that is consistent with the notion renal excretion plays a major role in the clearance of $\mathrm{Sb}$ in the fast elimination phase. Sb residual levels were particularly low in the brain. The pathophysiological consequences of $\mathrm{Sb}$ accumulation in the thyroid gland and the localisation of $\mathrm{Sb}$ forms within the liver, thyroid, spleen and bones warrant further studies.

\section{ACKNOWLEDGEMENTS}

To Rosangela De-Carvalho (blood sampling) and Rafael CC Rocha (ICP-MS analysis), for the technical assistance. The authors dedicate this paper to late Prof Norbert Fritz Miekeley, who introduced them in the study of kinetics of antimonybased drugs.

\section{REFERENCES}

Abdallah A, Saif M 1962. Trace studies with antimony 124 in man. In GEW Wolstenholme, M O'Connor (eds.), Bilharziasis, Ciba Foundation Symposium, Churchill, London, p. 287-309.

Bailly R, Lauwerys R, Buchet JP, Mahieu P, Konings J 1991. Experimental and human studies on antimony metabolism: their relevance for the biological monitoring of workers exposed to inorganic antimony. Br J Ind Med 48: 93-97.

Borborema SET, Osso Jr JA, de Andrade Jr HF, do Nascimento N 2013. Biodistribution of meglumine antimoniate in healthy and Leishmania (Leishmania) infantum chagasi-infected BALB/c mice. Mem Inst Oswaldo Cruz 108: 623-630.

Brady FJ, Lawton AH, Cowie DB, Andrews HL, Ness AT, Ogden GE 1945. Localization of trivalent radioactive antimony following intravenous administration to dogs infected with Dirofilaria immitis. Am J Trop Med 25: 103-107.

Christopherson JB 1918. The successful use of antimony in bilharziosis. Lancet 7: 325-327.

Christopherson JB 1923. The curative dose of antimony tartrate in schistosomiasis (bilharzia disease). Br Med J 2 (3287): 1254-1255.

Chulay JD, Fleckenstein L, Smith DH 1988. Pharmacokinetics of antimony during treatment of visceral leishmaniasis with sodium stibogluconate or meglumine antimoniate. Trans $R$ Soc Trop Med Hyg 82: 69-72.

Coelho DR 2010. Desenvolvimento somático, neurocomportamental e fertilidade da prole de ratos exposta ao antimoniato de meglumina pela via transplacentária e leite materno, MSc Dissertation, Fiocruz, Rio de Janeiro, 72 pp.

Di Cristina G, Caronia G 1915. Sulla terapia della leishmaniosi interna. Bulletin de la Société de Pathologie Éxotique 8: 63-65.

Dieter MP, Jameson CW, Elwell MR, Lodge JW, Hejtmancik M, Grumbein SL, Ryan M, Peters AC 1991. Comparative toxicity and tissue distribution of antimony potassium tartrate in rats and mice dosed by drinking water or intraperitoneal injection. $J$ Toxicol Environ Health 34: 51-82.

Ferreira C dos S, Martins PS, Demicheli C, Brochu C, Ouellette M, Frézard F 2003. Thiol-induced reduction of antimony(V) into antimony(III): a comparative study with trypanothione, cysteinyl-glycine, cysteine and glutathione. Biometals 16: 441-446.

Friedrich K, Vieira FA, Porrozzi R, Marchevsky RS, Miekeley N, Grimaldi Jr G, Paumgartten FJ 2012. Disposition of antimony in rhesus monkeys infected with Leishmania braziliensis and treated with meglumine antimoniate. $J$ Toxicol Environ Health A 75: 63-75.

Goodwin LG, Page JE 1943. A study of the excretion of organic antimonials using a polarographic procedure. Biochem J 37: 198-209.

Gregus Z, Gyurasics A, Koszorús L 1998. Interactions between selenium and group Va-metalloids (arsenic, antimony and bismuth) in the biliary excretion. Environ Toxicol Pharmacol 5: 89-99.

Gyurasics A, Koszorús L, Varga F, Gregus Z 1992. Increased biliary excretion of glutathione is generated by the glutathione-dependent hepatobiliary transport of antimony and bismuth. Biochem Pharmacol 44: 1275-1281.

Haldar AK, Sen P, Roy S 2011. Use of antimony in the treatment of leishmaniasis: current status and future directions. Mol Biol Int 2011: 571242.

Kramer LB 1950. Antimony concentration in the thyroid gland and its effect upon metabolic rate and serum cholesterol level. B Johns Hopkins Hosp 86: 179-181.

Lynch BS, Capen CC, Nestmann ER, Veenstra G, Deyo JA 1999. Review of subchronic/chronic toxicity of antimony potassium tartrate. Regul Toxicol Pharmacol 30: 9-17.

Mebius RE, Kraal G 2005. Structure and function of the spleen. Nat Rev Immunol 5: 606-616.

Miekeley N, Mortari SR, Schubach AO 2002. Monitoring of total antimony and its species by ICP-MS and on-line ion chromatography in biological samples from patients treated for leishmaniasis. Anal Bioanal Chem 372: 495-502. 
Miranda ES, Miekeley N, De-Carvalho RR, Paumgartten FJ 2006. Developmental toxicity of meglumine antimoniate and transplacental transfer of antimony in the rat. Reprod Toxicol 21: 292-300.

Molokhia MM, Smith H 1969. Tissue distribution of trivalent antimony in mice infected with Schistosoma mansoni. Bull World Health Organ 40: 123-128.

Nieto J, Alvar J, Mullen AB, Carter KC, Rodríguez C, San Andrés MI, San Andrés MD, Baillie AJ, González F 2003. Pharmacokinetics, toxicities and efficacies of sodium stibogluconate formulations after intravenous administration in animals. Antimicrob Agents Chemother 47: 2781-2787.

Otto GF, Maren TH, Brown HW 1947. Blood levels and excretion rates of antimony in persons receiving trivalent and pentavalent antimonials. Am J Hyg 46: 193-211.

Poon R, Chu I, Lecavalier P, Valli VE, Foster W, Gupta S, Thomas B 1998. Effects of antimony on rats following 90-day exposure via drinking water. Food Chem Toxicol 36: 21-35.

Quiroz W, Aguilar L, Barría M, Veneciano J, Martínez D, Bravo M, Lobos MG, Mercado L 2013. Sb(V) and Sb(III) distribution in human erythrocytes: speciation methodology and the influence of temperature, time and anticoagulants. Talanta 115: 902-910.

Quiroz W, De Gregori I, Basilio P, Bravo M, Pinto M, Lobos MG 2009. Heavy weight vehicle traffic and its relationship with antimony content in human blood. J Environ Monit 11: 1051-1055.

Radwan MA, Al Jaser MH, Al Rayes ZR 2007. The effects of induced diabetes and cutaneous Leishmania infection on the pharmacokinetics of antimony in hamsters. Ann Trop Med Parasitol 101: 133-142.

Roberts WL, McMurray WJ, Rainey PM 1998. Characterization of the antimonial antileishmanial agent meglumine antimonate (glucantime). Antimicrob Agents Chemother 42: 1076-1082.

Tassi P, Ormas P, Madonna M, Carli S, Belloli C, De Natale G, Ceci L, Marcotrigiano GO 1994. Pharmacokinetics of N-methylglucamine antimoniate after intravenous, intramuscular and subcutaneous administration in the dog. Res Vet Sci 56: 144-150.

Vianna G 1912. Tratamento da leishmaniose tegumentar por injeções intravenosas de tártaro emético. Anais do VII Congresso Brasileiro de Medicina e Cirurgia 4: 426-428. 